\title{
The Need for Technology Management Education for Undergraduate Programs: A Conceptual Framework
}

\author{
Murat Tas ${ }^{1, *}$, H. Okan Yeloglu \\ ${ }^{1}$ Department of Business \& Entrepreneurship, San Antonio College, San Antonio, United States of America \\ ${ }^{2}$ Department of Technology \& Knowledge Management, Baskent University, Ankara, Turkey
}

Copyright $\bigcirc 2018$ by authors, all rights reserved. Authors agree that this article remains permanently open access under the terms of the Creative Commons Attribution License 4.0 International License

\begin{abstract}
As the National Research Council [17] described the technology management as "a process, which includes planning, directing, control and coordination of the development and implementation of technological capabilities to shape and accomplish the strategic and operational objectives of an organization", Technology Management education is becoming more important for solving problems within organizations. Therefore, institutions of higher education need to lead the way in developing programs, curriculums, departments, and institutes addressing and meeting the needs of industries and the organizations. In this paper we evaluate the need of technology management undergraduate programs and provide some insights about this need. We realize the importance of technology management in both industrial and academic contexts and how important it is to have an interaction and collaboration between the industry organizations and universities. However, there is a lack of technology education on undergraduate level at today's universities curriculum. While there are many graduate programs on technology management in universities around the world, scholars and practitioners are paying less attention to undergraduate programs on technology management education. Therefore, we focus more on technology management education in undergraduate programs by outlining several assumptions, proposing a conceptual framework based on current debates in literature, and articulating its importance in the academic field.
\end{abstract}

Keywords Technology Management, Technology Management Education, Undergraduate Programs, Knowledge Transfer

\section{Introduction}

Technology management is important in both academic and industrial contexts because of the symbiotic and subsequent relationship - what is taught is eventually applied. However, defining needs for both organizations and industries is extremely difficult in such complex environments. Because of its multidisciplinary approaches, debates on how to integrate those approaches with the academic fields can be evaluated in several ways. From the industry perspective, organizations in several industries are producing new products and services, integrating technologies with their missions, visions, and the goals, and at the same time, evaluating their competitive advantages and disadvantages among other organizations. To compete with the other organizations in other industries, organizations are constantly seeking new and more efficient ways to reduce new product development times and minimize fixed and variable costs. On a more macro level, global competition has forced industries to confront business technology related problems.

On the other hand, what really matters for technology management education is the interaction and collaboration between universities and the industry organizations and the subsequent efficient transfer of knowledge, improvements, and innovations in products, services, and technologies. This transferal can be evaluated in several ways. One way is how those features are transferred, their frequency, and whether universities and industries perceive it as a benefit or not. For example, identifying the right partners, developing the agreements, and building formal and informal relationships may be the foundation of this process. Another phase can be an operational phase, consisting of arranging meetings, trainings, and mentoring, consulting or making projects. As an outcome phase, evaluation would focus on previous phases, alternate outcomes, and feedback in further strengthening the integration. The other evaluation is how the academic arena meets industry needs. The academic engagement in mutual projects, transferring academic knowledge to industry, collaborating and writing articles, and reviewing the university-industry relations (Perkmann [19]) can be 
seen as major contributions. This is not a one-way street. Organizations seek technology improvements created or designed in universities. So, this two-way street must be considered and incorporated into how this interactional process is thought of and developed.

\section{Study Questions}

Based on these assumptions, we seek to answer three major study questions:

1. How can technology-related problems be managed?

2. Who will manage and implement the technologies in organizations specifically and in industries generally in complex environments?

3. How can technology management programs contribute for collaboration among universities and industries?

The answers to these questions will aid in drawing the conceptual framework, articulating its benefits, and providing insights and implications about what needs to be done, not only in future studies, but also between academia and industry.

\section{Study Overview}

To answer these questions, first we review the literature while viewing technology management as a process--how this process is evaluated in different contexts, and finding links between the process and technology management education. Second, we emphasize and discuss why technology management education must be taken, especially in undergraduate programs, and how such a program can be constructed. And finally, by combining and formulating the concepts of technology management and technology management education in undergraduate programs, we draw a framework and conclude with recommendations for further studies.

\section{Study Question 1: How Can Technology-related Problems Be Managed?}

Because technology management is an emerging field combining multiple disciplines (from management to engineering), it can be defined as a process or a procedure consisting of sub-processes. Some scholars (Gregory [6]; Phaal, Paterson \& Probert [20]) define the technology management framework in organizations as identification, selection, acquisition, and exploitation as an ongoing process. Technology identification is the initial sub-process, including the identification of existing technologies and new technologies for products and services and the processes within an organization (Gregory [6]). Jiang, Zhao, Li and Chen [9] described the second sub-process, technology selection, where the decision makers choose technology routes, policies, measures, and schemes to achieve some given economic, technology, and social goals in a specific economic environment. The third sub-process is the technology acquisition which can be external or internal and defined by Ehinomen and Adeleke [4] as "the whole body of the most efficient technical and organizational knowledge and information available for the production of goods and services together with the tools for achieving production". And the fourth and last sub-process is technology exploitation in improving the performance of products or manufacturing processes by utilizing the new technologies or scientific developments (Bigwood [1]).

By defining it as a process, the characteristics and processes of managing technology become easier to understand and implement in and among organizations. In addition, to managing sub-processes, the functions of the management (planning, organizing, staffing, coordinating and controlling) must be considered in detail. For example, the National Research Council [17] described the technology management as "a process, which includes planning, directing, control and coordination of the development and implementation of technological capabilities to shape and accomplish the strategic and operational objectives of an organization". On the other hand, Kerr and his colleagues [10] argued that the tools for managing technology could be combined with these functions of management to make those tools more appropriate, available, practically set, and made more intangible in organizations to make them more efficient.

To integrate these functions of management into technology, there are prerequisites for organizations to consider. Managing technology requires the use of both internal and external sources in areas not limited to human resources, financial investments, and more. Managing technology may lead to an organizational change.

\section{Study Question 2: Who Will Manage and Implement the Technologies in Organizations Specifically and in Industries Generally in Complex Environments?}

The current literature discusses the dynamics of technology management and implementation and the complexity of the environment. For example, internal management may require organizations to hire highly skilled managers or workers to identify problems and find creative solutions for dealing with them about the ongoing processes. On the other hand, innovations or new product developments can be highly complex, have high costs, research and development and commercialization issues which may affect the organizational performance. About these problems, Ortega, Garrida-Vega, and Dominguez [18] also argued that that organizational performance is influenced by how strategies are implemented and the role technology plays in creating sustainable business models. The flow of information in industries and improvements and advancements in technology, take the issue one step 
further when investigating emerging research areas.

Organizations learning to manage technology with internal and external sources and compete in complex and technological environments reach a critical point in obtaining knowledge. One way to obtain this knowledge is to focus on the essentials in managing technology education. The paradigm is not new and has been a research field for over 40 years (Van Wyk [23]; Kim [11]; Reismann [21]). Management of technology education covers strategic management, project management, R\&D management, new product development, innovation management, entrepreneurship, and information management. These types are management are interconnected and interdependent on each other depicted in the upcoming theoretical framework and model.

Management of technology education is becoming more important for solving problems by a collaboration between industries and universities. For example, universities offer various projects for industries to collaborate with universities in finding new markets, new industries and various types of innovations. Therefore, institutions of higher education need to lead the way in developing programs, curriculums, departments, and institutes addressing and meeting the needs of industries and the organizations. Because of increased attention to the management of technology in the 2000s, numerous universities now offer programs in Canada and US (Brent
\& Pretorius [2]; Yanez, Khalil, \& Walsh [24]; Zehner [25]).

\section{Study Question 3: How Can Technology Management Programs Contribute for Collaboration among Universities and Industries?}

The answer to study question 3 is to seek a rational explanation about why technology management programs are needed at the undergraduate level. The current literature indicates that the technology management is prevalent in graduate programs; however, courses vary widely in MBA and MS programs and other research areas. These programs in many countries especially in the United States include many interdisciplinary courses from management to engineering and from information technology to computer sciences. These courses and programs help people in understanding and explaining the needs of industries by integration. But the main problem is they are only being offered at the graduate level. These management of technology programs must be included in undergraduate studies because today's competition is different-skills and capabilities. Here is a list of some technology management programs in graduate level. The programs in the list are limited but programs can be found via the Internet.

Table 1. List of Selected Technology Management Programs in Graduate Level in Several Countries

\begin{tabular}{|c|c|c|c|}
\hline $\begin{array}{l}\text { Name of the University or } \\
\text { Institution }\end{array}$ & Country & Name of the Program & Web Site \\
\hline Tokyo Institute of Technology & Japan & $\begin{array}{c}\text { Technology and Innovation } \\
\text { Management }\end{array}$ & $\begin{array}{c}\text { http://www.titech.ac.jp/english/graduate_school/graduate_major } \\
\text { s/tim/ }\end{array}$ \\
\hline $\begin{array}{l}\text { Colombia University School of } \\
\text { Professional Studies }\end{array}$ & U.S.A. & Technology Management & http://sps.columbia.edu/technology-management \\
\hline $\begin{array}{l}\text { Brandeis University Graduate } \\
\text { Professional Studies }\end{array}$ & U.S.A. & Technology Management & $\begin{array}{c}\text { https://www.brandeis.edu/gps/student-courses/programs/listings } \\
\text { /it-management.html }\end{array}$ \\
\hline Aarhus University & Denmark & $\begin{array}{c}\text { Engineering - Technology Based } \\
\text { Business Development }\end{array}$ & http://kandidat.au.dk/en/technologybasedbusinessdevelopment/ \\
\hline ISCTE & Portugal & $\begin{array}{c}\text { Management of Services and } \\
\text { Technology }\end{array}$ & $\begin{array}{c}\text { http://www.mastersportal.eu/studies/161979/management-of-ser } \\
\text { vices-and-technology.html }\end{array}$ \\
\hline Samara University & Russia & $\begin{array}{l}\text { High-Technology Business } \\
\text { Management }\end{array}$ & http://ssau.ru/english/education/educational_programs_eng/296/ \\
\hline $\begin{array}{c}\text { ISM University of } \\
\text { Management and Economics }\end{array}$ & Lithuania & $\begin{array}{c}\text { Innovation and technology } \\
\text { Management }\end{array}$ & $\begin{array}{c}\text { http://www.mastersportal.eu/studies/47944/innovation-and-tech } \\
\text { nology-management.html }\end{array}$ \\
\hline
\end{tabular}


Nambisan and Wilemon [16] note that graduate management of technology programs vary from university to university and there is no single type of management of technology program. On the other hand, Horwitch and Stohr, [8] emphasize using computing and communications technology to improve and make more effective the management of technology education. For re-designing, the fundamentals and emerging challenges of technology management (for example, cost management, financial and funding issues, working with the qualified and talented blue and white collars) must be considered for both industries and academia. In addition, Kordova and Frank [13] assert that technology management must be considered a systems thinking perspective, emphasizing the interrelations among components as a whole. In their study, Mallick and Chaudhury [14] investigated the technology management programs in MBA programs and discussed areas like general business and engineering functions, business strategy; internal use of information and manufacturing technology, new product or service development, social and ethical issues, government policies, integration of technology and business strategy that must be taken as major courses. In addition to this point, Mosey [15] indicated new disciplines like technology entrepreneurship that must be integrated to the management of technology for creating opportunities for scholars to study in future. Considering the new disciplines, Fishman discusses [5] if intellectual property management can be a new subject in technology management curricula for supporting the sub processes in technology management like entrepreneurship, technology strategy, and technology transfer.

From the initial survey of graduate management programs, the variety of elements within the programs indicates, or at least seems to indicate, the lack of interconnectedness to the industries and businesses that they aim to serve, improve, and innovate in. In some of graduate management programs surveyed, the connection between industry and academia is made by including seasoned professionals as part of the instructional staff. This brings industry to the classroom. These professionals also maintain their ties to industry. The need for interconnectedness does not imply a standardization. This is not possible in the complex environment discussed. It does imply a need for alignment or focus, both short term and long term in the academic world and the industry world.

But our focus is not also to accept the technology as the only a driver of this kind any kind of development, the management of technology but also must address, assess and deepen existing levels of understanding at the entry level.

Our evolving concept and proposition indicate not only a need for undergraduate technology management programs, but their critical alignment with industry. The framework is adaptable and flexible. These proposed compositions and curriculums can bridge the gap from academic to industry and span across the graduate programs, facilitating their alignment and making the transition from academic to industry more seamless and more corroborating, a joint venture that promotes and invites a dialogue and understanding. This paves the way for a two-way street and development from both sides. It also allows a clearer view, and perhaps an orientation to the needs - present and future - in what is being taught and what is being practiced and applied. If developed and maintained, this orientation can become self-correcting and, in many ways, be encompassed by the organizational learning professed by Senge [22] and others. This learning is not automatic, nor is the implementation. Both require unimpeded traffic on the two-way street, an open dialogue that is constructive and challenging.

Our framework and emphasis on the need for an aligned technology management programs at the undergraduate level also stresses and implicates the same need at the graduate level. If at the same institution, key learning outcomes and curriculum and instruction need to be stair stepped and integrated. And some of these undergraduate programs may not have their counterpart graduate degree in the same department or college requiring an even more coordinated effort in integration. Admittedly undergraduate programs may not have been able to incorporate seasoned industry professionals on their teaching staff, but that does not prohibit connecting through upper management programs or more directly between university programs and industry. Both levels need to keep their focus on how knowledge is instilled and transferred on this two-way street between academia and industry. The same for industry. So, the metaphor of the two-way street has to start somewhere. Initially our starting points were undergraduate programs and industry; however, without including the thoroughfare of graduate technology management programs, the road is impeded, and knowledge traffic suffers to industry and back.

Current literature about designing specific undergraduate programs curriculums is restricted. For example, Koohang and colleagues [12] presented a model for designing an Information Technologies undergraduate program which is recommended by the Association for Computer Machinery/Institute of Electrical and Electronics Engineers-Information Technology model. Hauck [7] described an technology management curriculum which was developed and supported courses like engineering science, general business, technology processes. On the other hand, in their study, Downs and McAllen [3] studied and examined the academic performance of students in a technology Managements bachelor's program with several factors as age, total number of semester credit hours. Therefore, in this study we try to make a contribution to current literature about this specific technology management undergraduate program. 


\section{Theoretical Framework}

Recalling the interconnectedness of management knowledge, the following framework is formulated to envision what is required at the undergraduate level. Integration of several management areas like technology management, knowledge management and strategic management courses can be given in the first and/or second academic year. At the third and fourth semester, more areas like computer information systems, big data, data mining, and data analyses aided by softwares must be planned to design to create an effective undergraduate program. To raise the level of the awareness levels of undergraduate's university industry interaction must be taken more seriously. Examining more case studies about technology management in organizations in several industries, inviting more specialists to universities to tell the experiences what they had before, and collaborating with the students by giving projects to solve technology management problems can make the program more efficient. And developing and sustaining internships for technology management undergraduates create a more powerful network in keeping the road open between industry and academia. These road mapping efforts may be considered in supporting long-range planning of the universities. To sum up, Figure 1 shows the network of technology management with the other areas that are related directly or indirectly.

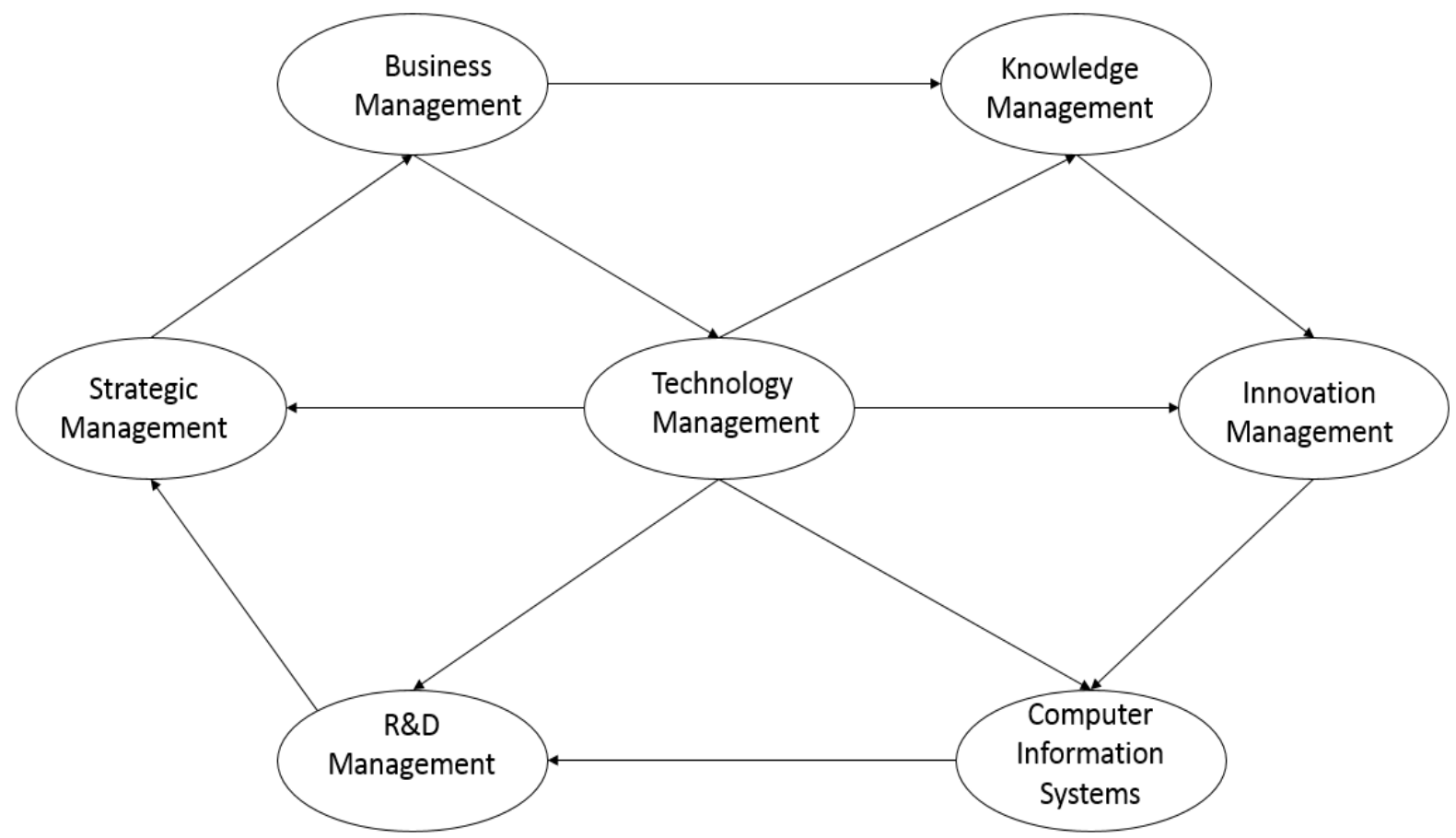

Figure 1. Proposed Technology Management Education Model in Undergraduate Programs (Developed by Yeloglu, 2017)

From the above figure, technology management is a multidisciplinary area, interconnected to multiple management types. The two-sided relationships can be evaluated as integral linkages but not unidirectional in maintaining. They can be related in many ways of interaction. Any undergraduate program in technology management must, at a minimum, contain these courses in the design, development, and execution of the curriculum. In addition, mandatory and elective courses must be designed and integrated into the full length of the undergraduate higher education. These courses not only must be designed on the bases of business management but also correlated and aligned with the needs of organizations - technology integration and strategic outcomes. Consequently, when undergraduate students graduate from these programs, they will be well equipped to transition into industries and make significant contributions.

More specifically the following knowledge and skills are crucial in an undergraduate degree in technology management:

- $\quad$ Providing knowledge and skills in technology applications

- Understanding how technology management can enhance productivity in training and information

- $\quad$ Developing both managerial and technical skills

- Developing a continuing understanding of computers and networks

- Understanding and applying convergence in technical networks

- Developing multidisciplinary skills - management, support, design, and other business applications-in both academic and workforce environments.

- $\quad$ And last, but not least, an internship that provides the opportunity for direct experience in the field. 


\section{An Example for Technology Management in Undergraduate Programs}

Our example is from Baskent University in Ankara Turkey, which has currently the only undergraduate degree in Technology and Knowledge Management in Department in Turkey. The 4 years program provides specific courses (both mandatory and selective) for students like technology management, knowledge management, information law, programming, quality management, research and development management. The short version of the catalog for the program is shown in Table 2. The full version of the program can be followed with the link http://angora.baskent.edu.tr/ankaraweb/katalog/katalog.php. And also, the outline of the courses is in http://angora.baskent.edu.tr/bilgipaketi/?dil=EN\&menu=akademik\&inner=katalog\&birim=342

Table 2. The short version of the catalog for the Technology and Knowledge Management Program

FACULTY OF ECONOMICS AND ADMINISTRATIVE SCIENCES

PROGRAM OF TECHNOLOGY AND KNOWLEDGE MANAGEMENT

\begin{tabular}{|c|c|c|c|c|c|c|}
\hline Univers & sity Compulsory Courses & & $\mathbf{T}$ & $\mathbf{P}$ & & CTS \\
\hline BTU100 & COMPUTER LITERACY & & 2 & - & 2 & 2 \\
\hline$\overline{\text { GSBHSH }}$ & FINE ARTS ELECTIVE/FIRST AID & & - & 2 & 1 & 1 \\
\hline ORY100 & INTRODUCTION TO UNIVERSITY LIFE & & 1 & - & 1 & 1 \\
\hline First Te & rm (Fall) & & $\mathbf{T}$ & $\mathbf{P}$ & $\mathbf{C}$ & CTS \\
\hline Term C & ourse Load : 6 courses, 19 credits & & & & & \\
\hline ECON101 & IINTRODUCTION TO ECONOMICS I & & 3 & - & 3 & 6 \\
\hline ENG125 & ENGLISH I & & 4 & - & 4 & 5 \\
\hline MAN105 & SOCIAL PSYCHOLOGY & & 3 & - & 3 & 6 \\
\hline$\overline{\text { MAN143 }}$ & MATHEMATICS I & & 4 & - & 4 & 6 \\
\hline TKM101 & INTRODUCTION TO TECHNOLOGY MANAGEMENT & & 3 & - & 3 & 5 \\
\hline TORK101 & TURKISH I & & 2 & - & 2 & 2 \\
\hline Second & Term (Spring) & & $\mathbf{T}$ & $\mathbf{P}$ & $\mathbf{C}$ & CTS \\
\hline Term C & ourse Load : 5 courses, 16 credits & & & & & \\
\hline ECON114 & IINTRODUCTION TO ECONOMICS II & & 3 & - & 3 & 8 \\
\hline ENG126 & ENGLISH II & (PRE:ENG125) & 4 & - & 4 & 5 \\
\hline MAN146 & MATHEMATICS & (PRE:MAN143) & 4 & - & 4 & 8 \\
\hline MAN164 & INTRODUCTION TO BUSINESS & & 3 & - & 3 & 7 \\
\hline TORK102 & TURKISH II & & 2 & - & 2 & 2 \\
\hline Third Te & erm (Fall) & & $\mathbf{T}$ & $\mathbf{p}$ & & CTS \\
\hline Term C & ourse Load : 7 courses, 21 credits & & & & & \\
\hline ATA201 & $\begin{array}{l}\text { ATATORK'S PRINCIPLES \& THE HIST. OF THE TURKISH } \\
\text { REVOLUTION I }\end{array}$ & & 2 & - & 2 & 2 \\
\hline ENG225 & ENGLISH III & (PRE:ENG126) & 4 & - & 4 & 5 \\
\hline MAN203 & BUSINESS LAW & & 3 & - & 3 & 3 \\
\hline MAN221 & PRINCIPLES OF ACCOUNTING I & & 3 & - & 3 & 5 \\
\hline MAN245 & STATISTICS I & & 3 & - & 3 & 5 \\
\hline MAN263 & ORGANIZATIONAL BEHAVIOUR & & 3 & - & 3 & 5 \\
\hline TKM203 & INTRODUCTION TO KNOWLEDGE MANAGEMENT & & 3 & - & 3 & 5 \\
\hline Fourth & Term (Spring) & & $\mathbf{T}$ & $\mathbf{P}$ & & CTS \\
\hline Term C & ourse Load : 6 courses, 18 credits & & & & & \\
\hline ATA202 & $\begin{array}{l}\text { ATATURK'S PRINCIPLES \& THE HIST. OF THE TURKISH REVOLUTION } \\
\text { II }\end{array}$ & & 2 & - & 2 & 2 \\
\hline ENG226 & ENGLISH IV & (PRE:ENG225) & 4 & - & 4 & 5 \\
\hline MAN222 & PRINCIPLES OF ACCOUNTING II & (PRE:MAN221) & 3 & - & 3 & 5 \\
\hline MAN248 & STATISTICS II & (PRE:MAN245) & 3 & - & 3 & 6 \\
\hline MAN252 & QUANTITATIVE BUSINESS ANALYSIS & & 3 & - & 3 & 7 \\
\hline TKM216 & INFORMATICS LAW & & 3 & - & 3 & 5 \\
\hline Fifth Te & erm (Fall) & & $\mathbf{T}$ & $\mathbf{P}$ & & CTS \\
\hline Term C & ourse Load : 6 courses, 19 credits & & & & & \\
\hline $\mathbf{x} \mathbf{x x \mathbf { x x } x}$ & ELECTIVE I & & 3 & - & 3 & 5 \\
\hline $\mathbf{x x x x x x}$ & ELECTIVE II & & 3 & - & 3 & 5 \\
\hline ENG367 & ENGLISH $v$ & $\begin{array}{l}\text { (PRE:ENG125 ENG126 ENG225 } \\
\text { ENG226) }\end{array}$ & 4 & - & 4 & 5 \\
\hline MAN355 & PRODUCTION AND OPERATIONS MANAGEMENT & & 3 & - & 3 & 5 \\
\hline TKM301 & WEB BASED APPLICATION DEVELOPMENT & & 1 & 2 & 3 & 5 \\
\hline TKM 321 & ORGANIZATIONAL DESING & & 3 & - & 3 & 5 \\
\hline Sixth Te & erm (Spring) & & $\mathbf{T}$ & $\mathbf{p}$ & C & CTS \\
\hline Term C & ourse Load : 6 courses, 19 credits & & & & & \\
\hline $\mathbf{x X X X X X}$ & ELECTIVE III & & 3 & - & 3 & 5 \\
\hline $\mathbf{x x x x x x}$ & ELECTIVE IV & & 3 & - & 3 & 5 \\
\hline $\mathbf{X X X X X X}$ & ELECTIVE V & & 3 & - & 3 & 5 \\
\hline ENG368 & ENGLISH VI & (PRE:ENG367) & 4 & - & 4 & 5 \\
\hline TKM324 & ENTREPRENEURSHIP AND INNOVATION MANAGEMENT & & 3 & - & 3 & 5 \\
\hline TKM376 & EFFICIENCY AND QUALITY MANAGEMENT & & 3 & - & 3 & 5 \\
\hline
\end{tabular}


Also, the key learning outcomes of the program are listed below with the link: http://angora.baskent.edu.tr/bilgipaketi/?dil=EN\&menu=a kademik\&inner $=$ programCiktilari\&birim $=342$

The students in this program;

1. Are equipped with up-to-date conceptual and applied knowledge of their field of study.

2. Can identify and understand problems of technology and knowledge management.

3. Can devise solutions to organizational or business problems using conceptual, applied, and methodological skills acquired during Program experience.

4. Can communicate effectively with expert and non-expert audiences regarding technology and knowledge management problems and solutions to them.

5. Can independently learn more and expand already acquired skills by applying them to new circumstances.

6. Can lead others as they deal with technology and knowledge management problems and help them acquire new skills and knowledge.

7. Write and speak fluently in English.

8. Are computer literate, can effectively use word processing, spreadsheet, and data management software.

9. Are ethically aware, know how business decisions affect those not directly involved in making of these decisions.

10. Are knowledgeable about laws, rules, and moral codes that apply to their field of work.

11. Are open-minded, willing to fight discrimination of all kinds in workplaces and business environment.

12. Are knowledgeable about fundamental environmental and social issues.

13. Know how technology and knowledge management topics are related to globalization.

\section{Conclusions}

Identifying the need for-undergraduate programs in technology management programs is easier than articulating how to make it happen. However, in this article, we provided insights how to make it possible. The conceptual framework can be further enhanced by scholars and industry specialists. But, providing a broad spectrum for undergraduate technology management means the needs of industry must be comprehensively re-assessed in detail. On the other hand, considering globalization and the internalization now crucial for organizations to survive, undergraduate programs must be re-designed and integrated with not only a long term view of industry and societal needs, but also a deeper knowledge of the organizational dynamics.
Industries need not only engineers and technical professionals, but also technology management graduates to find creative and innovative ideas and apply them using business and knowledge management, information systems, and innovation management. This process involves inputs-technology planning and development, implementation, diffusion and technological change, forecasting, basic and applied research, product design, development and integration, and assessment and substitution. Along with inputs are outputs of new knowledge, invention and innovation, use of technology in products and services, and reevaluating and coping with technology.

\section{REFERENCES}

[1] Bigwood, M. P. (2004). Managing the new technology exploitation process. Research \& Technology Management, 47(6): 38-42.

[2] Brent, A. C., \& Pretorius, M. W. (2008). Sustainable development: A conceptual framework for the technology management field of knowledge and a departure for further research. South African Journal of Industrial Engineering, 19(1), 31-52.

[3] Downs, G. H., \& McAllen, D. K. (2012, July). The effect of intrinsic motivation on success in a technology management undergraduate program. In Technology Management for Emerging Technologies (PICMET), 2012 Proceedings of PICMET'12: (pp. 1845-1849). IEEE.

[4] Ehinomen, C. \& and Adeleke, A. (2012), Strategies for Re-positioning Small and Medium Scale Enterprises in Nigeria for Global Competitiveness, E3 Journal of Business Management and Economics, 3, No. 7, 266-274.

[5] Fishman, E. A. (2010). The role of intellectual property management education in a technology management curriculum. The Journal of Technology Transfer, 35(4), 432-444.

[6] Gregory, M. J. (1995). Technology management: a process approach. Proceedings of the Institution of Mechanical Engineers, Part B: Journal of Engineering Manufacture, 209(5), 347-356.

[7] Hauck, A. J. (1999). A model undergraduate university curriculum in technology management. International Journal of Technology Management, 17(7-8), 830-839.

[8] Horwitch, M., \& Stohr, E. A. (2012). Transforming technology management education: Value creation-learning in the early twenty-first century. Journal of Engineering and Technology Management, 29(4), 489-507.

[9] Jiang H, Zhao S, Li Z, Chen Y (2016) Interaction between technology standardization and technology development: a co-piling effect study. Inf Techno Manag, 17, 229-243.

[10] Kerr, C., Farrukh, C., Phaal, R., Probert, D., (2013) Key principles for developing industrially relevant strategic technology management toolkits. Technological 
Forecasting and Social Change, 80 (6), 1050-1070.

[11] Kim, W. (2015). The current transition in management of technology education: The case of Korea. Technological Forecasting and Social Change, 100, 5-20.

[12] Koohang, A., Riley, L., Smith, T., \& Floyd, K. (2010). Design of an information technology undergraduate program to produce IT versatilists. Journal of Information Technology Education: Research, 9(1), 99-113.

[13] Koral-Kordova, S., \& Frank, M. (2014, July). Technology management education for improving systems thinking. In Management of Engineering \& Technology (PICMET), 2014 Portland International Conference on (pp. 1507-1514). IEEE.

[14] Mallick, D. N., \& Chaudhury, A. (2000). Technology management education in MBA programs: a comparative study of knowledge and skill requirements. Journal of Engineering and Technology Management, 17(2), 153-173.

[15] Mosey, S. (2016). Teaching and research opportunities in technology entrepreneurship. Technovation, 57, 43-44.

[16] Nambisan, S., \& Wilemon, D. (2003). A global study of graduate management of technology programs. Technovation, 23(12), 949-962.

[17] NRC/National Research Council, 1987. Management of Technology: The Hidden Competitive Advantage. National Academy Press, Washington, DC.

[18] Ortega, C. H., Garrido-Vega, P., \& Dominguez Machuca, J. A. (2012). Analysis of interaction fit between manufacturing strategy and technology management and its impact on performance. International Journal of Operations \&
Production Management, 32(8), 958-981.

[19] Perkmann, M., V. Tartari, M. McKelvey, E. Autio, A. Broström, P. D'Este, R. Fini (2013). Academic Engagement and Commercialization: A Review of the Literature on University-Industry Relations." Research Policy 42 (2): $423-442$.

[20] Phaal, R., Paterson, C. J., \& Probert, D. R. (1998), Technology management in manufacturing business: process and practical assessment. Technovation, 18(8), 541-589.

[21] Reisman, A. (1994). Technology management: a brief review of the last 40 years and some thoughts on its future. IEEE Transactions on Engineering Management, 41(4), 342-346.

[22] Senge, P., Kleiner, A., Roberts, C., Ross, R., Roth, Gl. And Smith, B. (1999) The Dance of Change: The Challenges of Susteining Momentum in Lerning Organizations, New York: Doubleday/Currency).

[23] Van Wyk, R. J. (2014). Technology-conversant management education: Introducing a new discipline. South African Journal of Industrial Engineering, 25(1), 1-13.

[24] Yanez, M., Khalil, T. M., \& Walsh, S. T. (2010). IAMOT and education: defining a technology and innovation management (TIM) body-of-knowledge (BoK) for graduate education (TIM BoK). Technovation, 30(7), 389-400.

[25] Zehner, W. B. (2000). The management of technology (MOT) degree: a bridge between technology and strategic management. Technology analysis \& strategic management, 12(2), 283-291. 